\title{
GAMBARAN PENGETAHUAN TENTANG PHUBBING AKIBAT KECANDUAN GADGET PADA GENERASI Z DI SMA NEGERI 9 KOTA PEKANBARU PROVINSI RIAU Bayu Abdurrahman $^{1}$, Yulia Febrianita ${ }^{2}$, Ainil Fitri $^{3}$
}

\author{
Mahasiswa Program Studi D III Keperawatan Universitas Abdurrab \\ Jl.Riau Ujung No.73,Pekanbaru,Riau \\ Bayu_Abdurrahman@yahoo.com \\ 1. Dosen Program Studi D III Keperawatan Universitas Abdurrab \\ Jl.Riau Ujung No.73,Pekanbaru,Riau \\ Yulia.ferbianita@univrab.ac.id \\ 2. Dosen Program Studi D III Keperawatan Universitas Abdurrab \\ Jl.Riau Ujung No.73,Pekanbaru,Riau \\ Ainil.fitri@univrab.ac.id
}

\begin{abstract}
Based on Wearesocial reports, there are some astonishing facts. Among them are the number of world internet users that have reached 4.021 billion people. This means that more than half of humans on earth have used the internet. The 2014 survey conducted by the Indonesian Internet Service Providers Association showed that internet users in Riau Province numbered 1.8 million. The purpose of this research was to find out the Knowledge Picture of Phubbing due to Gadget Addiction in the Generation Z in State High School 9 of Pekanbaru City in Riau Province in 2019. This type of research is descriptive. The Sampel in this study was Generation $Z$ in the State High School 9 of Pekanbaru Riau which numbered 100 students. The measurement of this study uses the Guttman scale. According to Sugiono (2012). The data collection tool in this study uses a questionnaire that is a number of written questions that are used to obtain information from the respondent in the sense of a report about his personality or things he knows (Arikuno, 2009) The results of this study stated that as many as 25 people (25\%) in the good category, as many as 53 people (53\%) in the category of adequate while 22 people (22\%) in the category of less. This research can be used as a suggestion for information and can be continued for further researchers by using different methodology techniques and different regions with the same research title.
\end{abstract}

Keywords: Knowledge, Phubbing, Gadget, SmartPhone

\begin{abstract}
ABSTRAK
Menurut laporan Wearesocial terdapat beberapa fakta mencengangkan. Diantaranya adalah tentang jumlah pengguna internet dunia yang telah mencapai 4,021 miliar orang. Ini artinya sudah lebih dari separuh manusia di bumi telah menggunakan internet. Survey tahun 2014 yang di lakukan oleh Asosiasi Penyelengara Jasa Internet Indonesia menunjukkan bahwa pengguna internet di Provinsi riau berjumlah 1,8 juta jiwa. Tujuan penelitian ini di lakukan untuk mengetahui Gambaran Pengetahuan Tentang Phubbing Akibat Kecanduan Gadget Pada Generasi Z di SMA Negeri 9 Kota Pekanbaru Provinsi Riau Tahun 2019. Jenis peneltian ini adalah deskriptif. Sampel pada penelitian ini adalah Generasi Z di SMA Negeri 9 Kota Pekanbaru Riau Yang berjumlah 100 orang siswa/i. Pengukuran penelitian ini menggunakan skala Guttman.Menurut Sugiono (2012). Alat pengumpulan data pada penelitian ini menggunakan kuesioner yaitu sejumlah pertanyaan tertulis yang digunakan untuk memperoleh informasi dari responden dalam arti laporan tentang pribadinya atau hal-hal yang
\end{abstract}


dia ketahui (Arikuno, 2009) Hasil penelitian ini menyatakan sebanyak 25 orang (25\%) dalam katagori baik, sebanyak 53 orang $(53 \%)$ dalam katagori cukup sedangkan 22 orang (22\%) dalam katagori kurang. Penelitian ini dapat dijadikan sebagai saran informasi serta dapat dilanjutkan bagi peneliti selanjutnya dengan menggunakn teknik metodologi yang berbeda dan wilayah berbeda dengan judul penelitian yang sama.

Kata kunci : Pengetahuan, Phubbing, Gadget, SmartPhone

\section{PENDAHULUAN}

Phubbing adalah sebuah istilah tindakan yang tidak memperdulikan seseorang di dalam sebuah lingkungan karena lebih fokus pada gadget dari pada membangun sebuah percakapan. Istilah ini mulai sering terdengar dan populer bersmaan dengan pesatnya perkembangan smartphone di pasaran. Di era modern seprti sekarang dengan segala kemudahan yang ditawarkan, seseorang sering lupa akan dampak negatifnya, contohnya adalah apa yang disebut dengan perilaku Phubbing. Seseorang dengan perilaku phubbing terindikasi menyakiti orang lain dengan pura-pura memperhatikan saat diajak berkomunikasi, tetapi pandangannya sebentar-sebentar tertuju pada smartphone yang ada di tangannya. (Hanika, 2015)

Menurut Kupperschmidt (2000) (dalam Putra, 2016) Generasi Z adalah kelahiran tahun 1995 - 2000 generasi yang paling muda yang baru memasuki angkatan kerja.Generasi ini biasanya disebut dengan generasi internet atai Igeneration.Generasi $\mathrm{Z}$ lebih banyak berhubungan sosial lewat dunia maya.Sejak kecil, generasi ini sudah banyak dikenalkan oleh teknologi dan sangat akrab dengan smartphone dan dikategorikan sebagai generasi yang kreatif.Karakteristiknya lebih menyukai kegiatan sosial dibandingkan generasi sebelumnya, lebih suka di perusahaan start up, multi tasking, sangat menyukai teknologi dan ahli dalam mengoperasikan teknologi tersebut, peduli terhadap lingkungan, mudah terpengaruh terhadap lingkungan mengenai produk ataupun merek-merek, pintar dan mudah untuk menangkap informasi secara cepat Perbedaan karakteristik yang paling signifikan antara generasi $\mathrm{X}, \mathrm{Y}$ dan $\mathrm{Z}$ adalah penguasaan informasi dan teknologi.
Siswa SMA adalah individu yang sedang mengalami masa remaja akhir (late adolescence) berada pada usia 15 sampai 18 tahun.Sedangkan masa remaja dimulai kirakira usia 10 tahun dan berakhir antara usia 18 sampai 22 tahun. Perubahan pada biologis, kognitif dan sosial emosional yang terjadi berkisar dari perkembangan fungsi seksual, proses berfikir abstrak sampai pada kemandirian. Remaja awal dan akhir mendapat status yang lebih baik dalam masyarakat dari tahun 1920 sampai tahun 1950.Pada tahun 1950, masa yang kita sebut remaja telah menjadi matang. Remaja telah memiliki identitas fisik dan sosial (Santrock, 2003)

Berdasarkan laporan Wearesocial terdapat beberapa fakta mencengangkan.Diantaranya adalah tentang jumlah pengguna internet dunia yang telah mencapai 4,021 miliar orang. Ini artinya sudah lebih dari separuh manusia di bumi telah menggunakan internet.(Ramadhan, 2017) internet di seluruh dunia. Hasilnya, mereka menyebut Indonesia sebagai Negara dengan pertumbuhan jumlah pengguna internet terbesar di dunia. Pada tahun 2016, jumlah pengguna internet sekitar 88,1 juta jiwa dan pada awal tahun 2017 mengalami peningkatan jumlah pengguna internet di tanah air sebesar 51 persen sekitar 132,7 juta. Namun dari sisi perangkat yang digunakan untuk mengakses internet, tidak ada perubahan yang berarti. Sebanyak 69 persen masyarakat Indonesia masih mengakses internet melalui perangkat mobile dan sisanya melalui desktop dan tablet. (Ramadhan, 2017).Survey tahun 2014 yang di lakukan oleh Asosiasi Penyelengara Jasa Internet Indonesia menunjukkan bahwa 
pengguna internet di Provinsi riau berjumlah 1,8 juta jiwa.

SMA Negeri (SMAN) 9 Pekanbaru, merupakan salah satu Sekolah Menengah Atas Negeri yang ada di Provinsi Riau, Indonesia.Sama dengan SMA pada umumnya di Indonesia masa pendidikan sekolah di SMAN 9 Pekanbaru ditempuh dalam waktu tiga tahun pelajaran, mulai dari Kelas X sampai Kelas XII.Didirikan pada tahun 1985.Kepala sekolah yg pertama Dra. Widasih Sekolah ini memliki 2 jurusan yaitu ipa dan ips. Sekolah ini sangat berprestasi baik dalam akademik maupun non akademik.Dalam bidang akademik, banyak prestasi yang didapatkan.Sekolah ini juga pernah mewakili Riau dalam ajang perlombaan Olimpiade Sains di Institut Pertanian Bogor.Selain itu, SMAN 9 memliki prestasi dalam bidang non akademik, terutama bidang kesenian.Tingkat ekonomi siswa di SMAN 9 Pekanbaru bervariasi.Banyak juga anak-anak berprestasi namun kurang mampu yang mendapatkan beasiswa untuk bersekolah disini. Sekolah ini masuk pukul 7.00 pagi .SMAN 9 Pekanbaru adalah SMA Berkarakter Bangsa. SMAN 9 Pekanbaru merupakan salah satu sekolah yang menjadi acuan indeks prestasi untuk sekolah lain nya di pekanbaru. Pada tahun 2007, sekolah ini menggunakan Kurikulum Tingkat Satuan Pendidikan sebelumnya dengan KBK.

\section{HASIL DAN PEMBAHASAN}

Hasil penelitian yang dilakukan pada tanggal 23 Mei 2019 dengan jumlah responden 100 orang dengan menggunakan kuesioner di SMA Negeri 9 Kota Pekanbaru Provinsi Riau tentang Phubbing akibat kecanduat Gadget di SMA Negeri 9 Kota Pekanbaru Provinsi Riau dapat dilihat pada table dibawah ini:

\section{Data Umum}

\section{Tabel 1}

Distribusi Frekuensi Berdasarkan Umur di SMAN9 Kota Pekanbaru 2019
Pada saat penulis melakukan survey awal dengan metode wawancara pada 10 orang responden tentang gambaran pengetahuan tentang phubbing pada Siswa/siswi di SMA N 9 Pekanbaru mendapatakan hasil 3 dari responden pernah mendengar kata-kata phubbing di media sosial, dan 7 lainya tidak mengetahui istilah phubbing. Belum adanya surve mendalam mengenai data pengethuan tentang phubbing padaSiswa/siswi SMA N 9 Pekanbaru terkait tingginya penggunaan internet di provinsi riau dan kecanduan media sosial, menjadi alasan ketertarikan saya untuk melakukan penelitian ini. Dari uraian di atas, penelitian ini dilakukan untuk mengetahui"Gambaran Pengetahuan Tentang Phubbing Akibat Kecanduan Gadget Pada Generasi Z di SMA Negeri 9 Kota Pekanbaru Provinsi Riau Tahun 2019”

\section{METODE PENELITIAN}

Penelitian ini menggunakan jenis penelitian kuantitatif, penelitian merupakan penelitian deskriptif. Penelitian dilakukan pada tahun 2019, bertempat di SMAN 09 Pekanbaru. Populasi dalam penelitian ini adalah siswa/siswi SMAN 09 Pekanbaru berjumlah 999 orang di Pekanbaru. Jumlah sampel penelitian ini adalah 100 orang dengan menggunakan teknik sampel, cluster sampling. Instrument penelitian menggunakan kuisioner dengan skala Guttman.

\begin{tabular}{|c|c|c|c|}
\hline No & $\begin{array}{c}\text { Klasifikasi } \\
\text { Umur }\end{array}$ & $\begin{array}{c}\text { Fre } \\
\text { kue } \\
\text { nsi } \\
(\mathbf{f})\end{array}$ & $\begin{array}{c}\text { Persen } \\
\text { tase } \\
(\boldsymbol{\%})\end{array}$ \\
\hline 1 & 16 tahun & $\mathbf{3 2}$ & $\mathbf{3 2}$ \\
\hline 2 & 17 tahun & $\mathbf{3 4}$ & $\mathbf{3 4}$ \\
\hline 3 & 18 tahun & $\mathbf{3 4}$ & $\mathbf{3 4}$ \\
\hline \multicolumn{2}{|c|}{ Jumlah } & $\mathbf{1 0 0}$ & $\mathbf{1 0 0 \%}$ \\
\hline
\end{tabular}

Berdasarkan table 1 dapat dilihat, dari 100 responden di SMA Negeri 9 Kota Pekanbaru di dapatkan data bahwa mayoritas responden berumur 17-18 tahun yang masing-masing 34 orang (34\%) 
Tabel 2

Distribusi Frekuensi Jenis Kelamin di SMAN 9 Kota Pekanbaru 2019

\begin{tabular}{|c|c|c|c|}
\hline $\begin{array}{c}\text { N } \\
\text { o }\end{array}$ & $\begin{array}{c}\text { Jenis } \\
\text { Kelamin }\end{array}$ & $\begin{array}{c}\text { Freku } \\
\text { ensi } \\
(\mathbf{f})\end{array}$ & $\begin{array}{c}\text { Pers } \\
\text { entas } \\
\text { e } \\
(\boldsymbol{\%})\end{array}$ \\
\hline 1 & Laki-laki & $\mathbf{6 2}$ & $\mathbf{6 2}$ \\
\hline 2 & Perempuan & $\mathbf{3 8}$ & $\mathbf{3 8}$ \\
\hline & Jumlah & $\mathbf{1 0 0}$ & $\begin{array}{c}\mathbf{1 0 0} \\
\%\end{array}$ \\
\hline
\end{tabular}

Dari tabel 2 dapat dilihat, dari 100 responden di SMA Negeri 9 Kota Pekanbaru di dapatkan data bahwa mayoritas responden berjenis kelamin Laki-laki sebanyak 62 orang (62\%)

Tabel 3

Distribusi Frekuensi Siswa/i yang memperoleh informasi tentang Phubbing akibat kecanduan Gadget di SMAN 9 Kota Pekanbaru 2019

\begin{tabular}{|c|c|c|c|}
\hline $\begin{array}{c}\text { N } \\
\text { o }\end{array}$ & $\begin{array}{c}\text { Memper } \\
\text { oleh } \\
\text { informa } \\
\text { si }\end{array}$ & $\begin{array}{c}\text { Frekue } \\
\text { nsi } \\
(\mathbf{f})\end{array}$ & $\begin{array}{c}\text { Persent } \\
\text { ase } \\
(\%)\end{array}$ \\
\hline $\mathbf{1}$ & Pernah & $\mathbf{2 5}$ & $\mathbf{2 5}$ \\
\hline $\mathbf{2}$ & $\begin{array}{c}\text { Tidak } \\
\text { Pernah }\end{array}$ & $\mathbf{7 5}$ & $\mathbf{7 5}$ \\
\hline \multicolumn{2}{|c|}{ Jumlah } & $\mathbf{1 0 0}$ & $\mathbf{1 0 0 \%}$ \\
\hline
\end{tabular}

Dari tabel 3 dapat dilihat, dari 100 orang responden di SMA Negeri 9 Kota Pekanbaru di dapatkan hasil bahwa responden yang mayoritas tidak pernah mendapat informasi tentang Phubbing akibat kecanduan gadget sebanyak 75 orang $(75 \%)$.

Tabel 4

Distribusi Frekuensi Siswa/I

Berdasarkan Sumber Informasi tentang Phubbing akibat kecandua Gadget di SMAN 9 Kota Pekanbaru 2019

\begin{tabular}{|l|c|c|c|}
\hline N & Sumber & Freku & Perse \\
o & Informa & ensi & ntase \\
\hline
\end{tabular}

\begin{tabular}{|c|c|c|c|}
\hline & si & (f) & $(\%)$ \\
\hline 1 & Guru & 2 & 8 \\
\hline 2 & $\begin{array}{l}\text { Tenaga } \\
\text { Kesehata } \\
\text { n }\end{array}$ & $\mathbf{0}$ & $\mathbf{0}$ \\
\hline 3 & $\begin{array}{l}\text { Koran/M } \\
\text { ajalah }\end{array}$ & 5 & 20 \\
\hline 4 & Televisi & $\mathbf{0}$ & $\mathbf{0}$ \\
\hline 5 & $\begin{array}{l}\text { Media } \\
\text { Online }\end{array}$ & 15 & 60 \\
\hline 6 & $\begin{array}{l}\text { Penyuluh } \\
\text { an }\end{array}$ & $\mathbf{0}$ & $\mathbf{0}$ \\
\hline 7 & $\begin{array}{l}\text { Materi } \\
\text { Pelajara } \\
\mathrm{n}\end{array}$ & $\mathbf{0}$ & $\mathbf{0}$ \\
\hline 8 & $\begin{array}{l}\text { Sebutkan } \\
\text { lainya } \\
\text { (orang } \\
\text { tua) }\end{array}$ & 3 & 12 \\
\hline \multicolumn{2}{|r|}{ Jumlah } & 25 & $100 \%$ \\
\hline
\end{tabular}

Dari tabel 4 dapat dilihat, dari 25 orang responden yang pernah mendapatkan informasi tentang Phubbing akibat kecanduan Gadget di SMA Negeri 9 Kota Pekanbaru di dapatkan hasil mayoritas mendapatkan informasi dari media online sebanyak 15 orang $(60 \%)$, dan sisahnya mendapatkan informasi dari guru, koran/majalah, dan orang tua.

\section{Data Khusus}

\section{Tabel 5}

Distribusi Frekuensi Siswa/I

Berdasarkan Pengetahuan Tentang

Phubbing Akibat Kecanduan

Gadget di SMAN 9 Kota Pekan Baru 2019

\begin{tabular}{|c|l|c|c|}
\hline $\begin{array}{c}\text { N } \\
\text { o }\end{array}$ & $\begin{array}{c}\text { Katagor } \\
\text { i } \\
\text { Pengeta } \\
\text { huan }\end{array}$ & $\begin{array}{c}\text { Freku } \\
\text { ensi } \\
(\mathbf{f})\end{array}$ & $\begin{array}{c}\text { Persen } \\
\text { tase } \\
(\%)\end{array}$ \\
\hline 1 & Baik & 25 & 25 \\
\hline 2 & Cukup & 53 & 53 \\
\hline 3 & Kurang & 22 & 22 \\
\hline \multicolumn{2}{|c|}{ Jumlah } & $\mathbf{1 0 0}$ & $\mathbf{1 0 0 \%}$ \\
\hline
\end{tabular}


Dari tabel 5 dapat dilihat dari 100 orang responden bahwa pengetahuan tentang Phubbing akibat kecanduan Gadget di SMA 9 Kota Pekanbaru, dalam katgori baik yaitu sebanyak 25 orang (25\%), dalam katgori cukup baik sebanyak 53 orang (53\%), dan dalam katagori kurang sebanyak 22 orang $(22 \%)$.

\section{PEMBAHASAN}

Dari hasil penelitian yang dilakukan pada tanggal 23 mei 2019 di SMA Negeri 9 Kota Pekanbaru yang berjudul "Gambaran Pengetahuan Phubbing Akibat Kecanduan Gadget Pada Generasi Z Di SMA Negeri 9 Kota Pekanbaru Provinsi Riau Tahun 2019" yaitu dari 100 orang responden bahwa pengetahuan tentang Phubbing akibat kecanduan Gadget di SMA 9 Kota Pekanbaru, dalam katgori baik yaitu sebanyak 25 orang $(25 \%)$, dalam katgori cukup baik sebanyak 53 orang (53\%), dan dalam katagori kurang sebanyak 22 orang $(22 \%)$.

Dari hasil penelitian diatas kita dapat ketahui bahwa mayoritas Pengetahuan Siswa/siswi tentang Phubbung akibat kecandua Gadget berada pada katagori cukup baik. Pengetahuan adalah hasil pengindraan manusia atau hasil tahu seseorang terhadap obyek melalui indra yang dimilikinya (mata, hidung, telinga, dan sebagainya) (Notoadmojo 2012). Hal Hal yang di maksud tahu disini bahwa semakin sering induvidu ataupun seseorang mendapatkna informasi maka semakin tinggi pula pengetahuan yang di dapat. Hal ini sejalan dengan penelitian yang di lakukan di SMA Negeri 9 Kota Pekanbaru mayoritas belum mendapat informasi tentang Phubbing akibat kecanduan Gadget.

Menurut Ariani 2014 pada sumber
informasi
menyediakan bemajuan teknologi
masa yang dapat mempengaruhi

pengetahuan masayarakat tentang informasi baru, seperti televise, radio, surat kabar, majlah, penyuluhan dan lainlain. dari penelitain ini diketahui dari 100 orang responden sumber informasi yang di peroleh siswa/I di SMA 9 kota Pekanbaru yang paling banyak yaotu dari media online sebanyak 15 orang (15\%).

Usia merupakan rentang waktu seseorang yang dimuali sejak dia dilahirkan hingga berulang tahun. Jika seseorang itu memiliki usia yang cukup maka akan memiliki pola piker yang matang. Usia sangatberpengaruh terhadap daya tangkap sehingga penetahuan diperolehnya akan semakin baik. Selain factor usia, factor pendidikan juga mempengaruhi pengetahuan siswa/I untuk menembangkan kepribadian hidup. Pendidikan mempengaruhi proses beljar, semakin tinggi pendidikan seseorang makan semakin mudah orang tersebut untuk menerima informasi.

Didapatkan hasil penelitian yang sama oleh peneliti bahwa pengetahuan dan pemahaman siswa/i SMA tentang kecanduan Gadget sebagat faktor pencentus Phubbing yang dengan hasil perhitungan terdapat 23 orang dapat menjawab 4 soal yang benar, 13 orang dapat menjawab 4 soal yang benar, dan 7 orang dapat menjawab 1 soal yang benar, bahwa pengetahuan siswa/i tentang Phubbing akibar kecanduan Gadget di katagorikan cukup baik.

Dari hasil penelitian diatas didapatkan bahwa data umum yang menunjukan bahwa 53 orang (53\%) dari 100 respon dalam katagori cukup yang mana hal ini sejalan dengan data jumlah responden yang memperoleh informasi tentang phubbing sebanyak 25 orang (25\%).

Hal ini sejalan dengan penelitain yang dilakukan oleh Yuna yusnita, dalam jurnal ilmiah mahasiswa FISIP Unsyiah tahun 2017 yang meneliti tentang pengaruh prilaku phubbing akibat penggunaan smartphone berlibihan terhadap interkasi sosial mahasiswa, 
dengan hasil penilitian terbukti dari 100 responden, sebanyak 66 responden $(66 \%)$ menyatakan bahwa frekuensi penggunaan smartphone dalam sehari mereka lakukan sepanjang hari.

Asumsi peneliti terhadap gambaran pengetahuan tentang Phubbing akibat kecanduan Gadget pada generasi Z di SMA Negeri 9 Kota Pekanbaru Riau bahwa mereka belum mengerti apa itu Phubbing dan dampak dari Phubbing itu sendiri.

\section{KESIMPULAN}

Hasil penelitian yang dilakukan pada tanggal 23 mei 2019 di SMA negeri 9 Kota Pekanbaru Ruau tentang Gambaran Pengetahuan Phubbing Akibat Kecanduan Gadget Generasi Z, secara keseluruhan mayoritas pengetahuan siswa/i berada pada katagori cukup baik yaitu 53 siswa/i (53 $\%)$

Berdasarkan hasil penelitian tersebut ada beberapa saran yang dapat disampaikan peneliti, antara lain : Diharapkan dapat mengadakan penyuluhan tentang Phubbing akibat kecanduan Gadget pada generasi Z di SMA Negeri 9 Kota Pekanbaru Riau. Diharapkan hasil penelitian ini dapat memperkaya konsep atau teori yang menyokong perkembangan ilmu di bidang kesehatang pisikologi tentunya dalam gaya hidup kurang sehat akibat kecanduan Gadget yang akan menyebakan terjadinya Phubbing generasi Z. Diharpakan kepada peneliti selanjutnya hasil penelitian ini dapat digunakna sebagai data dasar untuk acuan dan pedomandalam melakukan penelitian dengan penambahan variable dan sub variabel yang belum di teliti dalam peneliti ini sehingga mendapatkan pengetahuan dan wawasan yang baru dengan lebih baik. Dapat menambah bahan bacaan, masukan dan sumbangan bahan pemikiran yang dapat digunkan untuk mengetahui dampak negative dari kecanduan Gadget yang berdampak terjadinya Phubbing di kehidupan seharihari.

\section{REFERENSI}

Agus.(2013). Filsafat Ilmu Pengetahuan. (Diktat Kuliah). Pascasarjana Universitas Indonesia.

Ajo.(2014). Kemkominfo: Pengguna Internet Capai $82 \quad$ Juta (http://kominfo.go.id/index.php/co ntent/detail/3980/Kemkominfo\%3 A+Pengguna+Internet+di+Indonesi a+Capai+82+Juta/0/berita_satker\#. VQaCovmUf3E]. Diakses pada 8 Januari 2019

Bakhtiar, (2012). Filsafat Ilmu, Edisi Revisi, Cetakan XI, PT Raja Grafindo Persada, Jakarta.

Cornelly, Bill., (2018). Rule No. 1 For Dealing With Millennials In The Workplace. Diakses dari https://www.forbes.com/sites/billco nerly/2019/03/12/rule-number-onefor-dealing-with-millennials-intheworkplace/\#728f738f5c6f

Gusti. (2015) ”Analisis Pengaruh Media Sosial Twitter Terhadap Pembentukan Brand Attachment". Tesis Stud PT. XL AXIATA. ( Program Magister Manajemen, Fakultas Ekonomi, Universitas Indonesia). hal, 10-11

Hidayah.(2018). "Perilaku Phubbing Sebagai Karakter Remaja Generasi Z". Jurnal Fokus Konseling. Volume 4, No. 1 (2018). 143-152

Hanika.(2015). "Fenomena Phubbing Di Era Milenial". Jurnal Interaksi. Vol. 4 No. 1, Januari 2015. 42-51

Jensen, G., (2017). How to Manage Millennials: 8 Ways to Do it Right. Diakses dari https://guthriejensen.com/blog/8steps-tomanage-millennials/

Notoatmodjo, S.( 2010.)Metodologi Penelitian Kesehatan. Jakarta : Rineka Cipta. 
Notoatmodjo, 2010. Metode Penelitian Kesehatan. Jakarta: Rieneks Cipta.

Peter., (2015). 9 Powerful Tips for Communicating Better With Millennials. Diakses dari https://www.inc.com/petereconomy/9- powerful-tips-forcommunicating-better-withmillennials.html

Pinchot, dkk. (2010). How Mobile Technology is Changing Our Culture. CONISAR Proceedings Vol. 3 No. 1519. USA: Conference on Information Systems Applied Research

Putra. (2016). Generasi X,Y dan Z di era millennial.

(http://parent.binus.ac.id/wpcontent/uploads/2018/11/Generasi$\underline{\text { X-Y-Z.pdf). Diakses pada } 8 \text { januari }}$ 2019

Rahmawati. (2018) Relationship: Bahaya, Phubbing Bisa Mengancam Hubungan Sosialmu. (https://www.dewiku.com/relations hip/2018/08/03/133000/bahayaphubbing-bisa-mengancamhubungan-sosialmu). Diakses pada 7 januari 2019

Ramadhan. (2017) GNFI: Inilah Perkembangan Digital Indonesia Tahun 2018. (https://www.goodnewsfromindone sia.id/2018/02/06/inilahperkembangan-digital-indonesiatahun-2017) Diakse pada 8 januari 2019

Santrock, Adolescence., (2003) Perkembang Siswa Sma.Jakarta : Erlangga,

Yuna, M. Syam. (2017). "Pengaruh Perilaku Phubbing Akibat Penggunaan Smartphone Berlebihan Terhadap Interaksi
Sosial Mahasiswa".Jurnal Ilmiah Mahasiswa FISIP Unsyiah.Volume 2, Nomor 3, Agustus 2017. 7-9 